\title{
PROFESSOR FREI MANSUETO KOHNEN †
}

\section{R. BOSSMANN}

A 2 de julho de 1966 faleceu em Ruesselsheim, perto de Frank. furt na Alemanha, o Frei Mansueto Kohnen, O.F.M. As 7 horas daquela manhã, depois de longa enfermidade entregou sua alma ao Criador.

Segundo o desejo do falecido, seu corpo embalsamado, foi transportado para o Brasil, sua pátria adotiva, à qual dedicou sua vida servindo às almas como sacerdote, ao ensino como professor e às letras como pesquisador e literato.

As 15 horas do dia 9 de julho foi sepultado no Cemitério do Convento de Santo Antônio no Rio de Janeiro. Lá o Revmo. Frei Mansueto repousa após os incansáveis trabalhos realizados em vida. Descanse em Paz!

Transcrevemos trecho de carta recebida de amigo do saudoso desaparecido, descrevendo as últimas semanas de vida do eminente sacerdote e literato: "Frei Mansueto Kohnen esteve internado na Casa de Saúde São José, aqui no Rio. Como seu crganismo recusasse qualquer alimento sólido, o pobre doente vivia quase que exclusivamente de sôro. A fraqueza tomara tais proporşões, que mal podia suster-se em pé. Contudo, celebrava missa e conservava o bom humor que the era característico. Persuadido e auxiliado por amigos, resolveu ir à Alemanha, julgando poder encontrar melhoras. Dia 13 de junho, Frei Mansueto embarcou, tendo passado relativamente bem na viagem aérea. Em Frankfurt foi recebido por amigos e um médico, que logo cuidaram de sua remoção para o Hospital de Ruesselsheim. A 23 de junho foi tentada nova intervenção cirúrgica, mas em vão. Quando Frei Mansueto sentiu a proximidade da morte, recebeu os Santos Óleos e faleceu tranqüilo e plenamente conformado com a Vontade de Deus." 
Frei Mansueto nasceu a 18 de junho de 1910 em Aachen, na Renânia (Alemanha). Depois dos estudos de humanidades na Bélgica e os estudos filosóficos e teológicos no Brasil, lecionou no Colégio Diocesano de Lajes. Estudou sociologia e literatura brasileira na Faculdade de Filosofia da Universidade do Brasil. Era fundador da Cadeira de Literatura Alemã na Pontifícia Universidade Católica do Rio de Janeiro, Professor Catedrático de Língua e Literatura Alemã na Faculdade Nacional de Filosofia, Ciências e Letras da Universidade do Brasil.

Pela publicação de "Literatura Germânica", em 2 volumes, recebeu o grau de Dr. Litt. h.c. pelo Siena College de New York. Como Presidente da Associação Latino-Americana dos Professôres Catedráticos de Língua e Literatura Alemã, como cientista, autor e conferencista, prestou valiosa contribuição às Letras Alemãs e divulgou, de um modo especial, a literatura alemã. Seu nome ficará sempre ligado ao incremento da literatura alemã no território naciorial. Estudantes brasileiros orientaram-se e orientar-se-ão na literatur 3 da Alemanha através das obras eruditas do saudoso literato.

Sua obra principal é, sem dúvida, a "História da Literatura Ger. mânica", em 5 volumes, a mais rica história dêsto gênero em língua vernácula. Entre numerosas publicações literáries destacam-se também as seguintes:

"Síntese histórico-literária das Letras Germâricas".

"O Realismo nas Letras Germânicas do século XIX".

"O Romantismo na Literatura Germânica".

"Gertrud von le Fort e o Retôrno à ordem cristã".

"Gertrud von le Fort e a Idéia do Reich".

"O Expressionismo alemão e Reinhard Johannes Sorge".

Com o desaparecimento do Professor Frei Mansueto Kohnen, o Brasil perdeu um dos mais renomados e competentes literatos, e a Universidade Federal do Paraná um grande colaborador, e os colegas do Curso de Letras um sincero e fiel amigo. 